\title{
Estradiol-Induced Conditioned Place Preference may Require Actions at Estrogen Receptors in the Nucleus Accumbens
}

\author{
Alicia A Walf', Madeline E Rhodes ${ }^{2}$, Jonathan R Meade ${ }^{3}$, Jacob P Harney ${ }^{4}$ and Cheryl A Frye*, 1,2,5,6 \\ 'Department of Psychology, The University at Albany - SUNY, Albany, NY, USA; ²Department of Life Sciences Research, The University at Albany \\ - SUNY, Albany, NY, USA; ${ }^{3}$ Department of Psychology, University at Hartford, Hartford, CT, USA; ${ }^{4}$ Department of Biology, University at Hartford, \\ Hartford, CT, USA; ${ }^{5}$ Department of Biological Sciences Research, The University at Albany - SUNY, Albany, NY, USA; ${ }^{6}$ The Centers for \\ Neuroscience, The University at Albany - SUNY, Albany, NY, USA
}

\begin{abstract}
Intrinsic rewarding effects of estradiol $\left(E_{2}\right)$ may underlie some of the sex differences that emerge postpuberty for the prevalence of drug use and behavioral responses to drugs, but the effects and mechanisms of $E_{2}$ for reward have not been well characterized. Conditioned place preference (CPP), as measured by the time spent on the nonpreferred/drug-associated side of the chamber, was utilized as a functional assay to investigate the effects and mechanisms of $E_{2}$ in the nucleus accumbens for reward. To determine whether intracellular estrogen receptors (ERs) are important for $E_{2}$-induced CPP, rats were administered $E_{2}(10 \mu$; subcutaneously (s.c.)), which produced CPP in each experiment, and/or ER blockers, such as tamoxifen (Experiment I), ICl I82,780 (Experiment 2), or antisense oligonucleotides targeted to ERs (Experiment 3). Experiment $I$ : $E_{2}$ significantly increased the time spent on the originally nonpreferred side of the chamber. Coadministration of tamoxifen $\left(10 \mathrm{mg} / \mathrm{kg}\right.$; s.c.) attenuated effects of $E_{2}$ to produce a CPP, but tamoxifen alone, increased time spent on the nonpreferred side. Experiment 2: coadministration of $\mathrm{ICl} \mid 82,780(|0 \mu g / \mu|)$ to the nucleus accumbens attenuated effects of $E_{2}$ to enhance CPP and did not produce a CPP when administered alone. Experiment 3: coadministration of s.c. $E_{2}$ with ER antisense oligonucleotides to the nucleus accumbens significantly decreased time spent on the nonpreferred side and expression of ERs in the nucleus accumbens compared to scrambled antisense oligonucleotides or saline vehicle administration. Thus, $E_{2}$ 's rewarding effects may involve actions at ERs in the nucleus accumbens.
\end{abstract} Neuropsychopharmacology (2007) 32, 522-530. doi:I 0. I 038/sj.npp. I 30 I I24; published online 7 June 2006

Keywords: estrogen; tamoxifen; reward; affect; anxiety; SERMs

\section{INTRODUCTION}

There are sex differences in vulnerability to drug abuse among people and in animal models (SAMHSA, 2004; reviewed by Carroll et al, 2004). Clinical and animal model studies suggest that adult females may also be more vulnerable to drugs of abuse than are their male counterparts. Women begin cocaine use at a younger age than do men (Griffin et al, 1989) and can become addicted to abused substances, such as cocaine, opiates, and alcohol, faster than do men (Lex, 1991). Similarly, female rodents demonstrate quicker acquisition of cocaine, methamphetamine, and nicotine intravenous self-administration than do males (Caggiula et al, 2002; Carroll et al, 2001; Roth and Carroll,

*Correspondence: Dr CA Frye, Department of Psychology, Research, The University at Albany - SUNY, Life Sciences Research Building 01058,1400 Washington Avenue, Albany, NY 12222, USA, Tel: + I 5I8 59| 8839, Fax: + | 518 59| 8848, E-mail: cafrye@albany.edu Received 6 February 2006; revised 15 March 2006; accepted 16 March 2006

Online publication: 12 May 2006 at http://www.acnp.org/citations/ Npp05 | 206060072/default.pdf
2004). Thus, these data suggest that females may be more vulnerable to effects of drugs of abuse. However, potential mechanisms for these effects are yet to be determined.

One possible reason for sex differences in drug abuse may involve estradiol's $\left(E_{2}\right)$ effects to underlie or influence responses to drugs of abuse among people and animals. There are differences across the menstrual cycle in women's response to drugs. For instance, subjective responses to amphetamine (ie feelings of euphoria, liking/wanting, energy, and intellectual ability) are enhanced during the late follicular phase, when $E_{2}$ levels are rising, compared to the early follicular or luteal phase, when $E_{2}$ levels are lower (Justice and de Wit, 1999, 2000a). Indeed, there is a positive correlation between subjective responses to amphetamine and $E_{2}$ levels (Justice and de Wit, 1999). Furthermore, transdermal administration of $E_{2}$ to women in the follicular phase enhances subjective responses to amphetamine (Justice and de Wit, 2000b). Additionally, rodent models support a role for $\mathrm{E}_{2}$ in drug abuse. Naturally receptive rodents that have moderate physiological levels of $\mathrm{E}_{2}$ have increased hyperactivity after cocaine administration than do diestrous rats with lower levels of $\mathrm{E}_{2}$ (Sell et al, 
2002). Removal of the primary source of $E_{2}$, the ovaries (OVX), attenuates amphetamine-induced hyperactivity, cocaine-induced behavioral sensitization, and intravenous cocaine self-administration, which can be reversed by $\mathrm{E}_{2}$ replacement (Becker, 1990; Lynch et al, 2001; Peris et al, 1991). Thus, $\mathrm{E}_{2}$ may influence responses to drugs of abuse.

Drug abuse and neuropsychiatric disorders are often comorbid and, notably, $\mathrm{E}_{2}$ influences affect among women and in animal models (Walf and Frye, 2006). Women who abuse alcohol, cocaine, opiates, and/or nicotine have higher rates of mood and/or anxiety disorders than do men (Brooner et al, 1997; Borrelli et al, 1999; Cornelius et al, 1995; Lundy et al, 1995; McCance-Katz et al, 1999). Among women who have anxiety/mood disorders, $E_{2}$ therapy can enhance mood, but is dependent on the regimen utilized (Ahokas et al, 2001; Gregoire et al, 1996; Saletu et al, 1995; Schleifer et al, 2002; Smith et al, 1995). A similar pattern is observed in animal models. In naturally receptive rats, or OVX rats administered $\mathrm{E}_{2}$ regimen that produce physiological $\mathrm{E}_{2}$ levels, anxiety and depression behaviors are decreased (Estrada-Camarena et al, 2003; Frye et al, 2000; Frye and Walf, 2002, 2004; Frye and Wawrzycki, 2003; Nomikos and Spyraki, 1988; Rachman et al, 1998; Slater and Blizard, 1976; Walf and Frye, 2005a, b, 2006). Thus, these data suggest that $\mathrm{E}_{2}$ can alter affective responses.

$\mathrm{E}_{2}$ may have rewarding effects in the conditioned place preference (CPP) paradigm, which is used to elucidate effects of substances on reward (White and Carr, 1985). Subcutaneously (s.c.) administered $\mathrm{E}_{2}$ regimen that result in physiological $E_{2}$ levels in the nucleus accumbens of OVX rats produces a CPP (Frye and Rhodes, 2006). The nucleus accumbens is critical for CPP and is a target of $\mathrm{E}_{2}$. For example, $\mathrm{E}_{2}$ increases c-jun-immunoreactivity in the nucleus accumbens (Zhou and Dorsa, 1994). Whether $\mathrm{E}_{2}$ has requisite actions in the nucleus accumbens to mediate CPP is not known.

Given that $\mathrm{E}_{2}$ can alter responses to drugs of abuse, as well as produce rewarding effects, it is important to determine the mechanisms for these effects. $E_{2}$ alters other reward-related processes that increase dopamine release in the nucleus accumbens or striatum of female rats, such as wheel-running, locomotion, and pacing of copulatory contacts (Becker et al, 1987, 2001; as reviewed by Becker, 1999; Jenkins and Becker, 2003; Mermelstein and Becker, 1995; as reviewed by Lynch et al, 2002; Pfaus et al, 1995; Xiao and Becker, 1997). Pharmacological blockade of estrogen receptors (ERs) in these regions with the selective antagonist, ICI 182,780, but not tamoxifen (which can have both agonistic and antagonistic effects at ERs) attenuates $\mathrm{E}_{2}$-facilitated pacing behavior (Xiao and Becker, 1997; $\mathrm{Xiao}$ et al, 2003). Thus, one mechanism by which $\mathrm{E}_{2}$ may influence reward processes is through actions at ERs.

A specific binding site for $\mathrm{E}_{2}$ was identified over 40 years ago (Jensen and Jacobsen, 1962) and eventually became known as ERs. More recently, another $\mathrm{E}_{2}$ binding site with which $E_{2}$ interacts to have its functional effects has been identified (as reviewed by Kuiper et al, 1998). The original binding site is now referred to as $\operatorname{ER} \alpha$ and the newly identified binding site is referred to as $\operatorname{ER} \beta$. The nucleus accumbens expresses ERs (referring to both $\operatorname{ER} \alpha$ and $\operatorname{ER} \beta$;
Shughrue et al, 1997, 1998). Thus, we utilized a number of pharmacological tools to block ER action in the nucleus accumbens to address $E_{2}$ 's mechanisms in this region for reward.

In the present study, we investigated whether $E_{2}$-induced CPP requires actions at ERs in the nucleus accumbens. Rats were s.c. administered $\mathrm{E}_{2}$ and/or ER blockers, such as tamoxifen s.c. (Experiment 1), ICI 182,780 to the nucleus accumbens (Experiment 2), or antisense oligonucleotides targeted toward the originally identified binding site of $\mathrm{E}_{2}$ infused to the nucleus accumbens (Experiment 3). We hypothesized that if actions at ERs in the nucleus accumbens are required for $E_{2}$ 's rewarding effects, then coadministration of $\mathrm{E}_{2}$ in conjunction with ER blockers would attenuate $\mathrm{E}_{2}$-induced $\mathrm{CPP}$.

\section{MATERIALS AND METHODS}

These methods were preapproved by the Institutional Animal Care and Use Committee at SUNY-Albany.

\section{Animals and Housing}

Female Long-Evans rats $(N=140)$, approximately 55 days old, were obtained from the breeding colony in the Social Sciences Building at SUNY-Albany (original stock from Taconic Farms, Germantown, NY). Rats were group-housed (4-5 per cage) in polycarbonate cages $(45 \times 24 \times 21 \mathrm{~cm})$ in a temperature-controlled room $\left(21 \pm 1^{\circ} \mathrm{C}\right)$ in the laboratory animal care facility. Rats were maintained on a $12 / 12 \mathrm{~h}$ reversed light cycle (lights off 0800 hours) with continuous access to Purina rat chow and tap water.

\section{Surgery}

All rats were OVX under Rompun (12 mg/kg; Bayer Corp., Shawnee Mission, KS) and Ketaset $(80 \mathrm{mg} / \mathrm{kg}$; Fort Dodge Animal Health, Fort Dodge, IA) anesthesia. For Experiments 2 and 3, rats were stereotaxically implanted with cannulae (23 $\mathrm{G}$ ) aimed at the nucleus accumbens (from bregma AP = $+1.7, \mathrm{ML}= \pm 1.5, \mathrm{DV}=-6.0$; as per Paxinos and Watson, 1986; Frye et al, 2002). All rats were surgerized at least 1 week before testing.

\section{ER Blockade}

S.c. tamoxifen. In Experiment 1, rats were coadministered s.c. tamoxifen $(10 \mathrm{mg} / \mathrm{kg}$ s.c.; Sigma Chemical Co., St Louis, $\mathrm{MO}$ ), or vehicle (sesame oil and $10 \%$ ethanol), in conjunction with sesame oil vehicle or $\mathrm{E}_{2}\left(10 \mu \mathrm{g} / 0.2 \mathrm{~cm}^{3}\right.$; Sigma). As such, there were four groups ( $n=18$ /group) in this experiment: s.c. vehicle + s.c. vehicle, s.c. tamoxifen + s.c. vehicle, s.c. vehicle + s.c. $\mathrm{E}_{2}$, and s.c. tamoxifen + s.c. $\mathrm{E}_{2}$. S.c. administration of tamoxifen was utilized because it is an effective, albeit nonselective, ER antagonist that is bloodbrain barrier soluble. This tamoxifen regimen has been utilized to block $E_{2}$ 's effects on lordosis (Etgen and Shamamian, 1986) and anxiety behavior (Walf and Frye, 2005b).

Intranucleus accumbens ICI 182,780. In Experiment 2, rats were coadministered ICI $182,780(10 \mu \mathrm{g} / \mu \mathrm{l}$; Tocris 
Bioscience, Ellisville, MO), or vehicle ( $\beta$-cyclodextran) to the shell of the nucleus accumbens, in conjunction with s.c. injections of sesame oil vehicle or $E_{2}\left(10 \mu \mathrm{g} / 0.2 \mathrm{~cm}^{3}\right)$. As such, there were four groups in this experiment: intranucleus accumbens vehicle + s.c. vehicle $(n=14)$, intranucleus accumbens ICI $182,780+$ s.c. vehicle $(n=12)$, intranucleus accumbens vehicle + s.c. $\mathrm{E}_{2} \quad(n=17)$, and intranucleus accumbens ICI $182,780+$ s.c. $\mathrm{E}_{2}(n=10)$. ICI 182,780 was utilized because it is a specific ER antagonist and has been used successfully in our laboratory to investigate $\mathrm{E}_{2}$ 's effects on mnemonic processes and affective behavior (Frye and Rhodes, 2002; Walf and Frye, 2006).

Intranucleus accumbens antisense oligonucleotides. In Experiment 3, rats were administered saline vehicle $(n=4)$ or full phosphorothioate HPLC-purified mRNA antisense oligonucleotides (Genomechanix, Gainesville, FL). One group of rats was administered ER antisense oligonucleotides $(n=6)$, with the sequence, $5^{\prime}$-CAT-GGT-CAT-GGTCAG-3', that spans the putative translation start codon for rat $\mathrm{ER} \alpha$, and knocks down the translation of ER $\alpha$. Another group of rats was administered scrambled control antisense oligonucleotides $(n=4)$, with a 15 -mer sequence $\left(5^{\prime}\right.$-ATCGTG-GAT-CGT-GAC-3') that has the same base pairs, but the order randomized, and little or no homology to any mRNA sequences posted at GeneBank (NCBI BLAST search). Rats were infused with $\mathrm{ER} \alpha$ antisense oligonucleotides $(2 \mu \mathrm{g} / 1 \mu \mathrm{l}$; McCarthy et al, 1993), scrambled control oligonucleotides $(2 \mu \mathrm{g} / 1 \mu \mathrm{l})$, or saline vehicle immediately before administration of $E_{2}, 30$ min before placement on the nonpreferred side of the CPP chamber on days 4-5 and 8-9 (as described below in detail).

\section{CPP Paradigm}

The CPP paradigm used in the present study was as described previously (Frye and Rhodes, 2006). This paradigm includes the following four phases: habituation, baseline preference test, place preference conditioning, and place preference test.

Habituation (days 1 and 2): Rats were allowed to explore both sides of the conditioning chamber for 30 min each day.

Baseline preference test (day 3): Rats were placed in the chamber for $30 \mathrm{~min}$ and the amount of time spent on each side of the chamber was electronically recorded.

Place preference conditioning (days 4-11): A typical place preference conditioning procedure was utilized. Rats were administered drugs with putative conditioning properties (ie $E_{2}$ and/or ER blockers in the present experiment) before placement in the nonpreferred side of the chamber (as determined on day 3) on days 4-5 and 8-9. On days 6-7 and 10-11, all rats, irrespective of their experimental condition on conditioning days, were administered vehicle (appropriate to the experiment) immediately prior to placement in the originally preferred side of the apparatus.

Place preference test (day 12): Rats were placed in the apparatus with free access to both sides. The amount of time spent on each side was electronically recorded for a total duration of $30 \mathrm{~min}$. Time on the nonpreferred side is considered an index of CPP.

\section{Site Analyses}

After testing in Experiment 2, rats were perfused with $0.9 \%$ saline followed by $10 \%$ formalin. Brains were removed from the skull, fixed in formalin, and then sliced on a cryostat at $40 \mu \mathrm{m}$. Slices were then stained with cresyl violet and infusion location was determined with light microscopy. All but three rats received implants to the shell of the nucleus accumbens, which has previously been described as important for the modulation of CPP by steroids (Frye $e t$ al, 2002). The three rats that received bilateral implants to the core of the nucleus accumbens were not included in statistical analyses.

\section{Tissue Collection, Dissection, and Digestion}

In Experiment 3, rats were readministered their s.c. $\mathrm{E}_{2}$ and intranucleus accumbens antisense oligonucleotide regimen. Rats were rapidly decapitated, and brains were quickly removed from the skull, and placed on dry ice. Whole brains were stored at $-80^{\circ} \mathrm{C}$ until the nucleus accumbens and pituitary (as a positive control) were dissected out. Cannulae placement was verified during dissection. For dissections, brains were first gently thawed on ice. The nucleus accumbens and pituitaries were each placed in eppendorf tubes containing protease inhibitor cocktail dissolved in distilled water (Roche, 11836145001). Samples were transferred to test tubes on ice and were homogenized. Homogenized samples were then stored in the original eppendorf tubes containing the protease inhibitor overnight at $4^{\circ} \mathrm{C}$.

\section{Western Blot Analyses}

To verify effective knockdown of ERs with the antisense oligonucleotide strategy utilized, differences in ER protein expression in the nucleus accumbens with Western blotting were assessed. Standard Western blotting techniques were employed using polyclonal anti-rabbit antibodies against ER $\alpha$ (C1355; Upstate Biotechnology, Lake Placid, NY; Tanabe et al, 2004; Tanaka et al, 2004) to establish the extent to which the antisense oligonucleotides bound to the translation start sites of ER $\alpha$ and inhibited its translation into protein (Schreihofer et al, 2002). Western blotting analyses using a monoclonal anti-mouse $\beta$-actin antibody (A1978; Sigma) were also performed as a loading control. Briefly, homogenized samples were centrifuged for $20 \mathrm{~min}$ at $11 \times 1000 \mathrm{~g}$. Supernatant was separated from the pellet and stored at $-20^{\circ} \mathrm{C}$. A Bradford assay was then performed to determine protein concentration in each sample (Bradford, 1976). Using this information, $10 \mu \mathrm{g}$ of protein and sample buffer (50 mM Tris-Cl (pH 6.8), $100 \mathrm{mM}$ dithiothreitol, $2 \%$ SDS, $0.1 \%$ bromophenol blue, and $10 \%$ glycerol), yielding a final volume of $10 \mu \mathrm{l}$, were loaded onto $7.5 \times 10.0 \mathrm{~cm}$ gels. Samples were resolved on $10 \%$ SDS polyacrylamide gel utilizing $25 \mathrm{mM}$ Tris-glycine buffer, $\mathrm{pH} 8.3$, containing $20 \%$ methanol at $100 \mathrm{~V}$ for $1.5-2 \mathrm{~h}$ at room temperature, and electrophoretically transferred to nitrocellulose membrane (Pierce; with pore size of $0.45 \mu \mathrm{m}$ ) using a $25 \mathrm{mM}$ Tris-glycine buffer, $\mathrm{pH}$ 8.3, containing $20 \%$ methanol, at $100 \mathrm{~V}$ for $1.5 \mathrm{~h}$ at $4^{\circ} \mathrm{C}$. After transfer was complete, nitrocellulose membranes were blocked in 
Pierce's blocking buffer (Pierce, Rockford, IL) with $0.05 \%$ Tween- 20 overnight at $4{ }^{\circ} \mathrm{C}$. The membranes were washed in buffer (phosphate-buffered saline with $0.05 \%$ Tween-20) on a rocking platform before incubation with the primary antibodies for $\operatorname{ER} \alpha \quad(1: 1000$ dilution) or $\beta$-actin $(1: 1000$ dilution) in blocking buffer with $0.05 \%$ Tween-20 overnight at $4{ }^{\circ} \mathrm{C}$. After incubation with the primary antibody, membranes were washed in buffer on a rocking platform and were incubated with the appropriate horseradish peroxidase-labeled goat anti-rabbit $(1: 3000$ dilution for $\mathrm{ER} \alpha)$ or goat anti-mouse secondary antibody $(1: 5000$ dilution for $\beta$-actin) supplied in the chemiluminescence kit (Pierce, Supersignal West FEMTO Max Sensitivity kit; 34095), in blocking buffer with $0.05 \%$ Tween-20, for $1 \mathrm{~h}$ with agitation. Membranes were then washed in buffer, soaked in the chemiluminescence medium for $5 \mathrm{~min}$, and exposed to X-ray film, and film was developed.

\section{Statistical Analyses}

To determine mechanisms and effects of $\mathrm{E}_{2}$ for producing a place preference in these experiments, three-way analyses of variance (ANOVAs) were utilized in Experiments 1 and 2 to analyze effects of $E_{2}$ condition, ER blocker condition, and test occasion (baseline $v s$ test). Two-way ANOVAs were used to determine effects of infusion (antisense or scrambled oligonucleotides or vehicle) to OVX, $\mathrm{E}_{2}$-primed rats and time on CPP. Previous studies in our lab utilizing CPP have suggested that an $\alpha$ level of $P \leqslant 0.05$ is appropriate (Frye and Rhodes, 2006; Frye et al, 2002). Where appropriate, ANOVAs were followed by Fisher's post hoc tests with Bonferroni corrections to determine group differences. Although sample sizes varied across experiments, post hoc power analyses indicated that there was sufficient power in each experiment, minimally $70 \%$.

\section{RESULTS}

\section{Experiment 1: Effects of Systemic Tamoxifen (Figure 1)}

There were main effects of $\mathrm{E}_{2}$ condition $(\mathrm{F}(1,136)=5.9$, $P<0.02)$ and test occasion $(\mathrm{F}(1,136)=35.6, P<0.01)$ that was owing to $E_{2}$ significantly increasing time on the nonpreferred side during testing compared to vehicle. Although there was no significant main effect of tamoxifen, there was an interaction between $\mathrm{E}_{2}$ and tamoxifen $[\mathrm{F}(1,136)=12.8$, $P<0.01]$ that was owing to tamoxifen attenuating CPP in rats coadministered $E_{2}$, but not vehicle.

\section{Experiment 2: Effects of ICI 182,780 to the Nucleus Accumbens (Figure 2)}

There were main effects of $\mathrm{E}_{2}[\mathrm{~F}(1,98)=12.5, P<0.01]$, test occasion $[\mathrm{F}(1,98)=21.6, P \leqslant 0.01]$, and ICI 182,780 to the nucleus accumbens $[\mathrm{F}(1,98)=6.3, P \leqslant 0.01]$ and a significant interaction between all three variables $[\mathrm{F}(1,98)=5.4$, $P \leqslant 0.02]$. OVX, $\mathrm{E}_{2^{-}}$, but not vehicle-, primed rats administered ICI 182,780 spent significantly less time on the nonpreferred side of the chamber during testing than did rats infused with vehicle to the nucleus accumbens.

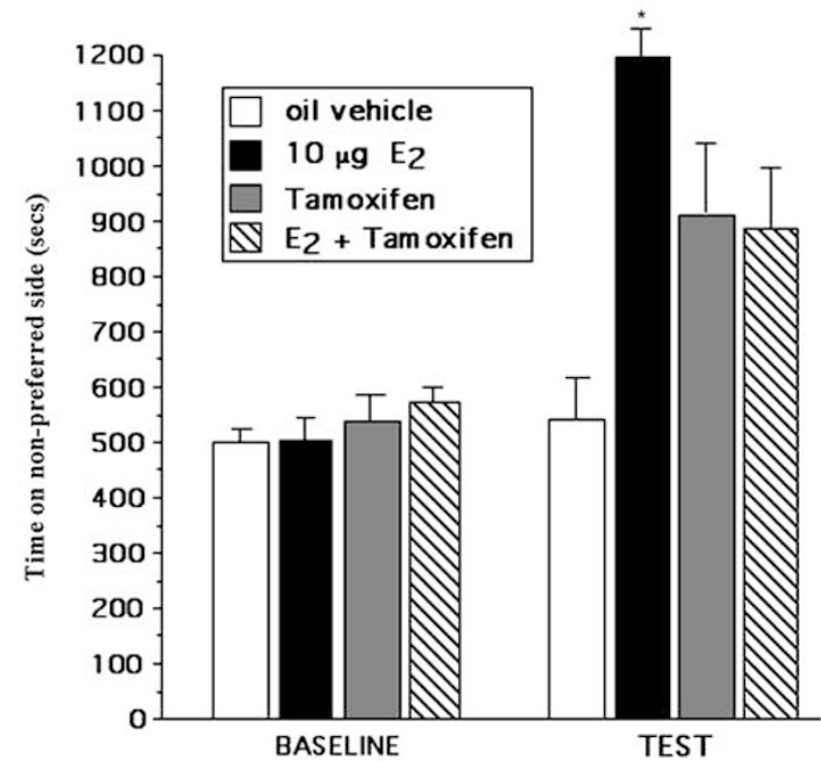

Figure I The mean $( \pm S E M)$ time spent on the nonpreferred side of the conditioning chamber. *Above bar indicates $E_{2}$ increases time spent on the nonpreferred side compared to s.c. oil vehicle administration $(P<0.05)$

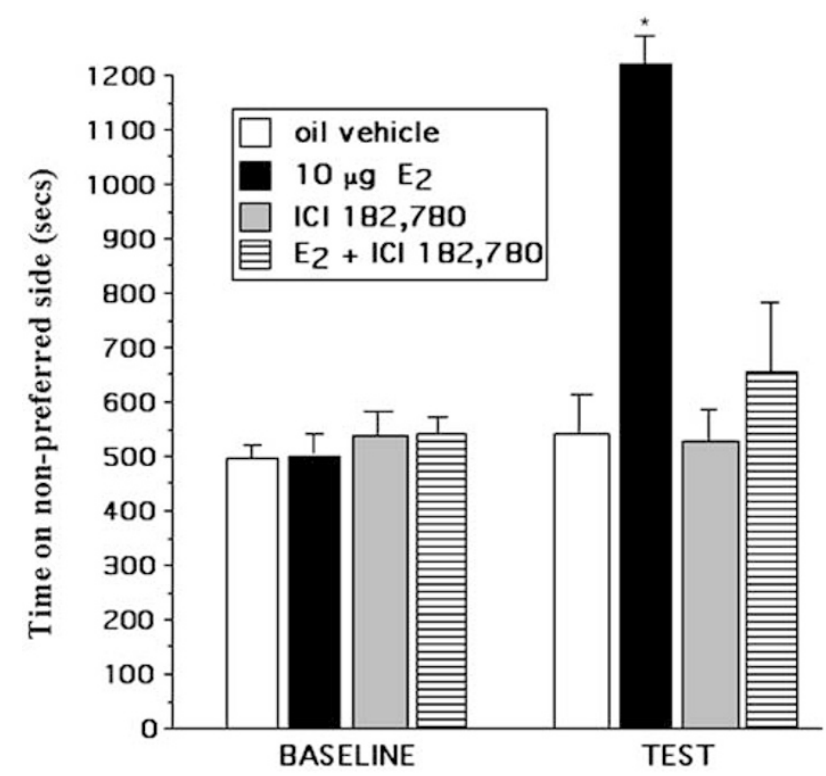

Figure 2 The mean $( \pm S E M)$ time spent on the nonpreferred side of the conditioning chamber. *Above bar indicates $E_{2}$ increases time spent on the nonpreferred side compared to all other groups $(P<0.05)$.

Experiment 3: Effects of ER Antisense Oligonucleotides to the Nucleus Accumbens (Figure 3)

There was a main effect of infusion condition $[\mathrm{F}(2,22)=5.0$, $P \leqslant 0.01]$ and test occasion $[\mathrm{F}(1,22)=22.2, P \leqslant 0.01]$ on place preference of $\mathrm{E}_{2}$-primed, OVX rats. Rats administered $\mathrm{E}_{2}$ and infused with ER antisense oligonucleotides to the nucleus accumbens spent significantly less time on the nonpreferred side of the chamber during testing than did $\mathrm{E}_{2}$-primed rats infused with scrambled antisense oligonucleotides or vehicle. 


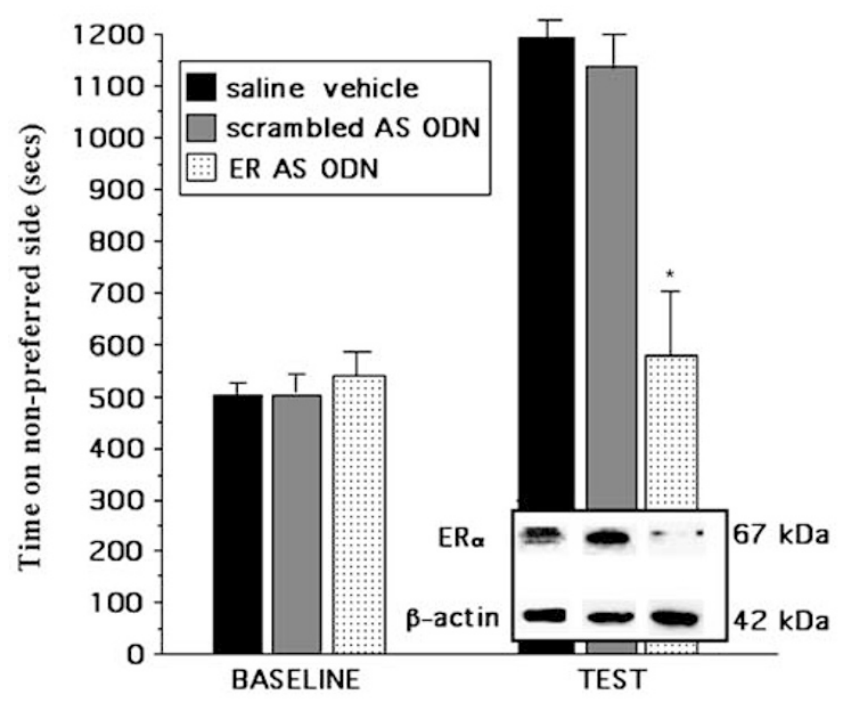

Figure 3 The mean $( \pm S E M)$ time spent on the nonpreferred side of the conditioning chamber. *Above bar indicates $E_{2}$ increases time spent on the nonpreferred side compared to intranucleus accumbens saline vehicle or scrambled control antisense oligonucleotide administration $(P<0.05)$. Inset depicts Western blot analyses of ER $\alpha$ and actin protein expression in the nucleus accumbens of these groups.

Efficacy of antisense oligonucleotide infusions is revealed by Western blot analyses. Western blots using the $\beta$-actin antibody revealed the presence of protein in samples. Compared to the administration of vehicle or scrambled control to the nucleus accumbens, bands for ER $\alpha$ in nucleus accumbens were not apparent (see Figure 3, inset), demonstrating that ERs were knocked down $24 \mathrm{~h}$ after s.c. $\mathrm{E}_{2}$ administration and $\mathrm{ER} \alpha$ antisense oligonucleotides infusion.

\section{DISCUSSION}

The present results supported our hypothesis that $\mathrm{E}_{2}$ 's effects to produce a CPP may be due in part to actions at ERs in the nucleus accumbens. S.c. administration of $\mathrm{E}_{2}$ increased time spent on the originally nonpreferred side of the chamber and this was consistently attenuated with coadministration of ER blockers. First, s.c. tamoxifen decreased time spent on the nonpreferred side of the chamber in rats coadministered $\mathrm{E}_{2}$, but also produced intrinsic effects when coadministered with vehicle. Second, administration of the specific ER antagonist, ICI 182,780, to the nucleus accumbens significantly decreased the time spent on the nonpreferred side of the chamber of rats administered $\mathrm{E}_{2}$ and did not produce intrinsic effects. Third, administration of ER antisense oligonucleotides to the nucleus accumbens of OVX, $\mathrm{E}_{2}$-primed rats significantly decreased time on the nonpreferred side and ER $\alpha$ expression in the nucleus accumbens compared to the administration of saline vehicle or scrambled control antisense oligonucleotides. Together, these data suggest that the ability of $E_{2}$ to produce a place preference may require actions at ERs in the nucleus accumbens.

The present data confirm previous studies on how $\mathrm{E}_{2}$ may alter aspects of reward and have intrinsic rewarding effects.
Here, we demonstrate that s.c. $\mathrm{E}_{2}$ administration to OVX rats increases time spent on the originally nonpreferred side of the CPP chamber, which replicates data from a previous experiment. We have previously shown that there are regimen-dependent effects of $\mathrm{E}_{2}$ to OVX rats to produce $\mathrm{CPP}$, which occur with dosages that produce physiological levels of $E_{2}$ in the nucleus accumbens, such as the $10 \mu \mathrm{g}$ regimen utilized here (Frye and Rhodes, 2006). These findings complement those from other models that demonstrate $\mathrm{E}_{2}$ also increases performance in other behavioral assays that are typically utilized to assess the rewarding properties of a substance, such as intracranial self-stimulation and self-administration. Naturally receptive and OVX, $\mathrm{E}_{2}$-administered rats have increased rates of intracranial self-stimulation than do rats with lower $\mathrm{E}_{2}$ levels (Steiner et al, 1982; as reviewed by Carroll et al, 2004). Hamsters intracerebroventricularly self-administer $\mathrm{E}_{2}$ (Dimeo and Wood, 2006). Furthermore, the present study extends these findings of the reinforcing effects of $E_{2}$ to suggest that actions at ERs in the nucleus accumbens may be important for $E_{2}$-mediated effects on reward.

Systemic administration of the mixed ER agonistantagonist, tamoxifen, attenuated $\mathrm{E}_{2}$-induced place preference and enhanced place preference in rats administered vehicle, suggesting that tamoxifen had some intrinsic effects on reward. Tamoxifen, like other selective ER modulators (SERMS), can have both agonistic and antagonistic actions at ERs, depending upon tissue target. This may explain why systemically administered tamoxifen (which could have actions throughout the brain) did not completely block $\mathrm{E}_{2}$-induced CPP and produced modest increases in place preference when coadministered with vehicle in the present study. Similar patterns of results have been shown previously with systemic tamoxifen administration. Tamoxifen demonstrated $\mathrm{E}_{2}$ mimetic effects in other systems. For example, systemic tamoxifen has effects similar to $\mathrm{E}_{2}$ to increase NMDA receptors in the brain (Cyr et al, 2001). In other situations, tamoxifen attenuates the effects of $E_{2}$. Tamoxifen administered s.c. attenuates antianxiety behavior of OVX rats administered $\mathrm{E}_{2}$ or SERMs specific to $\operatorname{ER} \beta$ (Walf and Frye, 2005b). As well, coadministration of $\mathrm{E}_{2}$ and tamoxifen via s.c. injections attenuated $E_{2}$ 's effects on cocaine self-administration (Lynch et al, 2001). There are also scenarios when there is no effect of tamoxifen. For example, tamoxifen is ineffective in altering changes in dopamine release in the striatum or pacing behavior of OVX, $\mathrm{E}_{2}$-primed rats (Xiao et al, 2003). Together, these data suggest that administration of ER ligands, such as $E_{2}$ and tamoxifen, can alter reward. However, whether ERs in the nucleus accumbens were required for effects of $E_{2}$ on reward were unclear, so this was further examined using more specific pharmacological tools.

Administration of the specific ER antagonist, ICI 182,780, to the nucleus accumbens attenuated $\mathrm{E}_{2}$-induced $\mathrm{CPP}$, without producing intrinsic effects on CPP. Other studies have demonstrated that ICI 182,780 has functional effects to attenuate behaviors modulated by $\mathrm{E}_{2}$. ICI 182,780 , but not tamoxifen, when administered to the dorsolateral striatum, blocks $\mathrm{E}_{2}$-facilitated pacing behavior (Xiao et al, 2003). Additionally, administration of a specific ER antagonist, ICI 182,780 , to the hippocampus increases anxiety and depression behavior of naturally receptive rats (Walf and Frye, 
2006). Although our results suggest that intracellular ERs are important, it is not entirely clear whether ICI 182,780 has antagonist effects at membrane and/or intracellular ERs ( $\mathrm{Gu}$ et al, 1999). In addition to actions at intracellular ERs, $\mathrm{E}_{2}$ can have rapid actions via membrane ERs or other membrane-bound receptors that initiate signal-transduction pathways (Beyer et al, 2002; Kelly and Levin, 2001; Moss and Gu, 1999; Nilsen et al, 2002; Toran-Allerand et al, 2002; Wade et al, 2001; Watters et al, 1997). Furthermore, it has been postulated that some of $\mathrm{E}_{2}$ effects at intracellular ERs are potentiated subsequent to the activation of membrane-associated ERs (Kow and Pfaff, 2004; Vasudevan et al, 2001). The nucleus accumbens expresses both ER isoforms; however, relatively low levels of intracellular ER mRNA or protein expression in the nucleus accumbens have been demonstrated (Shughrue et al, 1997, 1998; Shughrue and Merchenthaler, 2001). The expression of membrane ERs in this region is not clear and it may be that effects of $E_{2}$ in the nucleus accumbens are owing to an interaction of membrane and nuclear ERs. The design of the present experiment does not allow us to determine if $\mathrm{E}_{2}$ 's effects were rapid (ie occurring in less than 10-15 mins; Pfaff and McEwen, 1983) and through actions involving membrane receptors, but this could be addressed in future studies.

The third strategy that was utilized in the present experiments to investigate $E_{2}$ 's ER-mediated effects for reward was knockdown of ERs with infusions of ER-specific antisense oligonucleotides. We found that administration of $\mathrm{ER} \alpha$ antisense oligonucleotides to the nucleus accumbens produced significantly shorter time spent in the nonpreferred side of the chamber than did administration of vehicle or scrambled control antisense oligonucleotides. Another study has shown that a similar regimen of ER $\alpha$ antisense oligonucleotides via a single infusion to neonatal rats produced specific behavioral and morphological effects in adulthood (McCarthy et al, 1993). In the present study, there was no evidence for nonspecific behavioral effects of the antisense oligonucleotides, based upon neurological testing, which may have obviated effects of $E_{2}$ for CPP. Another aspect of this experiment to consider is the timing of the effects. Based upon previous studies utilizing similar antisense oligonucleotides regimen, protein knockdown occurs between 12 and $48 \mathrm{~h}$ following antisense oligonucleotide administration (McCarthy et al, 1994, 2000; Ogawa et al, 1994). Although we cannot know that, at the initial time of conditioning of $\mathrm{E}_{2}$ and ER antisense oligonucleotides ( $30 \mathrm{~min}$ after administration), expression of ERs was knocked down, knockdown of ERs at $24 \mathrm{~h}$ is consistent with the actions of $E_{2}$ at ERs being blocked by ER antisense oligonucleotides on the second day in the nonpreferred side of the CPP chamber and Western blot analyses.

The present study, using three strategies to block ERs, suggests that actions of $\mathrm{E}_{2}$ to produce a CPP may be dependent on activating intracellular ERs in the nucleus accumbens. However, these data need to be interpreted with some caution. There are limitations to the CPP paradigm as a model for addictive behaviors in humans (Bardo and Bevins, 2000; Ettenberg, 2004), such as modest face validity and the question of whether this is a task that measures conditioning to context rather than drugs' interoceptive effects. Future studies could use other models of reward to investigate the mechanisms of $\mathrm{E}_{2}$ for this effect further. Furthermore, there are potential differences in $\mathrm{E}_{2}$ 's effects in this paradigm owing to timing of treatment or regimen utilized. In this study, we have investigated short-term, acute treatment with $\mathrm{E}_{2}$. For instance, short-term effects of $\mathrm{E}_{2}$ for affective behavior are not the same as that seen with with longer treatment and/or higher dosing regimen (Luine et al, 1998; Morgan and Pfaff, 2001, 2002; Walf and Frye, 2006). Indeed, $\mathrm{E}_{2}$ produced place aversion and disrupted CPP, when high and/or chronic dosages were utilized (de Beun et al, 1991; Galea et al, 2001). Thus, the effects of $\mathrm{E}_{2}$ on behavior are mitigated by many factors, such as timing and dosage of $\mathrm{E}_{2}$ utilized, which need further investigation to determine the effects of $\mathrm{E}_{2}$ for chronic conditions, such as mood and anxiety disorders.

The importance of $\mathrm{E}_{2}$ acting at $\mathrm{ER} \alpha$ vs $\mathrm{ER} \beta$ needs to be addressed further. The pharmacological compounds used to block ERs vary in their specificity for blocking these isoforms. Although all blockers attenuated the effects of $E_{2}$, it is not clear if ICI 182,780 is specific for $E R \alpha$ or $\operatorname{ER} \beta$, there is suggestion that tamoxifen's antagonistic, but not agonistic, effects are through actions involving $\operatorname{ER} \beta$ (Watanabe et al, 1997) and the antisense oligonucleotides strategy was targeted toward $\mathrm{ER} \alpha$. However, these ER isoforms can interact for their functional effects (Lindberg et al, 2003; as reviewed by Toran-Allerand 2004), suggesting that the possibility remains that either isoform may be important. Indeed, studies investigating the putative roles of $\operatorname{ER} \alpha$ and $\operatorname{ER} \beta$ for cognitive processes, arousal, and affect suggest the importance of these ER isoforms. Studies utilizing SERMs or ER knockout mice support a role of both $\operatorname{ER} \alpha$ and $\operatorname{ER} \beta$ for learning and memory processes (Fugger et al, 2000; Luine et al, 2003; Rhodes and Frye, 2006; Walf et al, 2006) and $\mathrm{ER} \alpha$ for behavioral arousal (Ogawa et al, 2003; Pfaff et al, 2002). Studies utilizing knockout mice or $\operatorname{ER} \beta$ SERMs suggest that $\mathrm{E}_{2}$ 's actions at $\operatorname{ER} \beta$ may be important for its antianxiety and antidepressant-like effects. $\operatorname{ER} \beta$ knockout mice have increased anxiety (Krezel et al, 2001), and do not have reduced anxiety or depression behavior in response to $\mathrm{E}_{2}$ administration, as do their wildtype counterparts (Imwalle et al, 2005; Rocha et al, 2005; Walf and Frye, 2006). S.c. administration of $\operatorname{ER} \beta$, but not $\mathrm{ER} \alpha$, SERMs decrease anxiety and depressive behavior of OVX rats (Lund et al, 2005; Walf and Frye, 2005b; Walf et al, 2004). Some of $\mathrm{E}_{2}$ 's effects on reward processes and behavioral responses to drugs of abuse may be through interactions with the mesolimbic dopaminergic system (as reviewed by Becker, 1999) and $\operatorname{ER} \beta$. A recent report suggests that an ER $\beta$-specific SERM produces similar effects as does $E_{2}$ to increase $D_{2}$ receptor density in the striatum and nucleus accumbens (Le Saux et al, 2006). Thus, further investigation of $\mathrm{E}_{2}$ 's actions at $\operatorname{ER} \alpha$ and/or $\operatorname{ER} \beta$ and integration with the mesolimbic dopamine system for reward are warranted.

An interesting question is what other modulators, besides putative actions through ERs and/or the mesolimbic dopamine system, may underlie the effects of $E_{2}$ for reward and/or affective behaviors. One possibility is that some of $\mathrm{E}_{2}$ 's effects on reward and affective processes may be mediated by actions of the hypothalamic pituitary adrenal axis (HPA). Although $\mathrm{E}_{2}$ 's effects on glucocorticoid release among female rodents may be regimen dependent (Walf 
and Frye, 2005a), there is evidence that $\mathrm{E}_{2}$ administration increases corticosterone levels of rats administered cocaine (Niyomchai et al, 2005). Notably, studies investigating sex differences in relapse rates of drug users suggest that women are more likely to report relapse as a response to stressor exposure (Swan et al, 1988; Gritz et al, 1996; Snow and Anderson, 2000). Future studies should investigate how the HPA may contribute to the effects of $E_{2}$ through actions involving ERs on reward and affective processes.

In summary, these data suggest that $E_{2}$ 's actions to condition a place preference are due in part to actions at ERs in the nucleus accumbens. $\mathrm{E}_{2}$ administered s.c. produces a place preference in OVX rats. Administration of compounds that block ERs, administered systemically or to the nucleus accumbens, attenuated $\mathrm{E}_{2}$-induced place preference. It is important to further investigate the sites and mechanisms of action for $\mathrm{E}_{2}$ as a potential modulator of reward and affective processes.

\section{ACKNOWLEDGEMENTS}

This research was supported by a contract grant from the Lilly Centre for Women's Health at Eli Lilly and Company.

\section{REFERENCES}

Ahokas A, Kaukoranta J, Wahlbeck K, Aito M (2001). Estrogen deficiency in severe postpartum depression: successful treatment with sublingual physiologic $17 \beta$-estradiol: a preliminary study. J Clin Psychiatr 62: 332-336.

Bardo MT, Bevins RA (2000). Conditioned place preference: what does it add to our preclinical understanding of drug reward? Psychopharmacology 153: 31-43.

Becker JB (1990). Estrogen rapidly potentiates amphetamineinduced striatal dopamine release and rotational behavior during microdialysis. Neurosci Lett 118: 169-171.

Becker JB (1999). Gender differences in dopaminergic function in striatum and nucleus accumbens. Pharmacol Biochem Behav 64: 803-812.

Becker JB, Rudick CN, Jenkins WJ (2001). The role of dopamine in the nucleus accumbens and striatum during sexual behavior in the female rat. J Neurosci 21: 3236-3241.

Becker JB, Snyder PJ, Miller MM, Westgate SA, Jenuwine MJ (1987). The influence of estrous cycle and intrastriatal estradiol on sensorimotor performance in the female rat. Pharmacol Biochem Behav 27: 53-59.

Beyer C, Ivanova T, Karolczak M, Kuppers E (2002). Cell typespecificity of nonclassical estrogen signaling in the developing midbrain. J Steroid Biochem Mol Biol 81: 319-325.

Borrelli B, Marcus BH, Clark MM, Bock BC, King TK, Roberts M (1999). History of depression and subsyndromal depression in women smokers. Addict Behav 24: 781-794.

Bradford M (1976). A rapid and sensitive method for the quantification of microgram quantities of protein utilizing the principle of protein-dye binding. Anal Biochem 72: 248-252.

Brooner RK, King VL, Kidorf M, Schmidt Jr CW, Bigelow GE (1997). Psychiatric and substance use comorbidity among treatment-seeking opioid abusers. Arch Gen Psychiatr 54: 71-80.

Caggiula AR, Donny EC, White AR, Chaudhri N, Booth S, Gharib MA et al (2002). Environmental stimuli promote the acquisition of nicotine self-administration in rats. Psychopharmacology 163: 230-237.

Carroll ME, Campbell UC, Heideman P (2001). Ketoconazole suppresses food restriction-induced increases in heroin self- administration in rats: sex differences. Exp Clin Psychopharmacol 9: 307-316.

Carroll ME, Lynch WJ, Roth ME, Morgan AD, Cosgrove KP (2004). Sex and estrogen influence drug abuse. Trends Pharmacol Sci 25 273-279.

Cornelius JR, Jarrett PJ, Thase ME, Fabrega Jr H, Haas GL, JonesBarlock A et al (1995). Gender effects on the clinical presentation of alcoholics at a psychiatric hospital. Compr Psychiatr 36: 435-440.

Cyr M, Ghribi O, Thibault C, Morissette M, Landry M, Di Paolo T (2001). Ovarian steroids and selective estrogen receptor modulators activity on rat brain NMDA and AMPA receptors. Brain Res Brain Res Rev 37: 153-161.

de Beun R, Jansen E, Smeets MA, Niesing J, Slangen JL, van der Poll NE (1991). Estradiol-induced conditioned tase aversion and place aversion in rats: sex- and dose-dependent effects. Physiol Behav 50: 995-1000.

Dimeo AN, Wood RI (2006). Self-administration of estrogen and dihydrotestosterone in male hamsters. Horm Behav 49: 519-526.

Estrada-Camarena E, Fernandez-Guasti A, Lopez-Rubalcava C (2003). Antidepressant-like effect of different estrogenic compounds in the forced swimming test. Neuropsychopharmacology 28: $830-838$.

Etgen AM, Shamamian P (1986). Regulation of estrogen-stimulated lordosis behavior and hypothalamic progestin receptor induction by antiestrogens in female rats. Horm Behav 20: 166-180.

Ettenberg A (2004). Opponent process properties of self-administered cocaine. Neurosci Biobehav Rev 27: 721-728.

Frye CA, Petralia SM, Rhodes ME (2000). Estrous cycle and sex differences in performance on anxiety tasks coincide with increases in hippocampal progesterone and $3 \alpha, 5 \alpha$-THP. Pharmacol Biochem Behav 67: 587-596.

Frye CA, Rhodes ME (2002). Enhancing effects of estrogen on inhibitory avoidance performance may be in part independent of intracellular estrogen receptors in the hippocampus. Brain Res 956: 285-293.

Frye CA, Rhodes ME (2006). Administration of estrogen to ovariectomized rats promotes conditioned place preference and produces moderate levels of estrogen in the nucleus accumbens. Brain Res 1067: 209-215.

Frye CA, Rhodes ME, Rosellini R, Svare B (2002). The nucleus accumbens as a site of action for rewarding properties of testosterone and its $5 \alpha$-reduced metabolites. Pharmacol Biochem Behav 74: 119-127.

Frye CA, Walf AA (2002). Changes in progesterone metabolites in the hippocampus can modulate open field and forced swim test behavior of proestrous rats. Horm Behav 41: 306-315.

Frye CA, Walf AA (2004). Estrogen and/or progesterone systemically or to the amygdala can have anxiety, fear, and pain reducing effects in ovariectomized rats. Behav Neurosci 118: 306-313.

Frye CA, Wawrzycki J (2003). Effect of prenatal stress and gonadal hormone condition on depressive behaviors of female and male rats. Horm Behav 44: 319-326.

Fugger HN, Foster TC, Gustafsson J, Rissman EF (2000). Novel effects of estradiol and estrogen receptor $\alpha$ and $\beta$ on cognitive function. Brain Res 883: 258-264.

Galea LA, Wide JK, Paine TA, Holmes MM, Ormerod BK, Floresco SB (2001). High levels of estradiol disrupt conditioned place preference learning, stimulus response learning and reference memory but have limited effects on working memory. Behav Brain Res 126: 115-126.

Gregoire AJ, Kumar R, Everitt B, Henderson AF, Studd JW (1996). Transdermal oestrogen for treatment of severe postnatal depression. Lancet 347: 930-933.

Griffin ML, Weiss RD, Mirin SM, Lange U (1989). A comparison of male and female cocaine abusers. Arch Gen Psychiatr 46: $122-126$. 
Gritz ER, Nielsen IR, Brooks LA (1996). Smoking cessation and gender: the influence of physiological, psychological, and behavioral factors. J Am Med Womens Assoc 51: 35-42.

Gu Q, Korach KS, Moss RL (1999). Rapid action of $17 \beta$-estradiol on kainate-induced currents in hippocampal neurons lacking intracellular estrogen receptors. Endocrinology 140: 660-666.

Imwalle DB, Gustafsson JA, Rissman EF (2005). Lack of functional estrogen receptor $\beta$ influences anxiety behavior and serotonin content in female mice. Physiol Behav 84: 157-163.

Jenkins WJ, Becker JB (2003). Dynamic increases in dopamine during paced copulation in the female rat. Eur J Neurosci 18: 1997-2001.

Jensen EV, Jacobsen HI (1962). Basic guides to the mechanism of estrogen action. Recent Prog Horm Res 18: 387-414.

Justice AJ, de Wit H (1999). Acute effects of $d$-amphetamine during the follicular and luteal phases of the menstrual cycle in women. Psychopharmacology 145: 67-75.

Justice AJ, de Wit H (2000a). Acute effects of $d$-amphetamine during the early and late follicular phases of the menstrual cycle in women. Pharmacol Biochem Behav 66: 509-515.

Justice AJ, de Wit H (2000b). Acute effects of estradiol pretreatment on the response to $d$-amphetamine in women. Neuroendocrinology 71: 51-59.

Kelly MJ, Levin ER (2001). Rapid actions of plasma membrane estrogen receptors. Trends Endocrinol Metab 12: 152-156.

Kow LM, Pfaff DW (2004). The membrane actions of estrogens can potentiate their lordosis behavior-facilitating genomic actions. Proc Natl Acad Sci USA 101: 12354-12357.

Krezel W, Dupont S, Krust A, Chambon P, Chapman PF (2001). Increased anxiety and synaptic plasticity in estrogen receptor $\beta$-deficient mice. Proc Natl Acad Sci USA 98: 12278-12282.

Kuiper GGJM, Shughrue PJ, Merchenthaler I, Gustafsson JA (1998). The estrogen receptor $\beta$ subtype: a novel mediator of estrogen action in neuroendocrine systems. Front Neuroendocrinol 19: 253-286.

Le Saux M, Morissette M, Di Paolo T (2006). ER $\beta$ mediates the estradiol increase of $\mathrm{D}(2)$ receptors in rat striatum and nucleus accumbens. Neuropharmacology 50: 451-457.

Lex BW (1991). Some gender differences in alcohol and polysubstance users. Health Psychol 10: 121-132.

Lindberg MK, Moverare S, Skrtic S, Gao H, Dahlman-Wright K, Gustafsson JA et al (2003). Estrogen receptor (ER)- $\beta$ reduces $\mathrm{ER} \alpha$-regulated gene transcription, supporting a 'ying yang' relationship between $\mathrm{ER} \alpha$ and $\operatorname{ER} \beta$ in mice. Mol Endocrinol 17: 203-208.

Luine VN, Jacome LF, Maclusky NJ (2003). Rapid enhancement of visual and place memory by estrogens in rats. Endocrinology 144: 2836-2844.

Luine VN, Richards ST, Wu VY, Beck KD (1998). Estradiol enhances learning and memory in a spatial memory task and effects levels of monoaminergic neurotransmitters. Horm Behav 34: $149-162$.

Lund TD, Rovis T, Chung WC, Handa RJ (2005). Novel actions of estrogen receptor beta on anxiety-related behaviors. Endocrino$\log y$ 146: 797-807.

Lundy A, Gottheil E, Serota RD, Weinstein SP, Sterling RC (1995). Gender differences and similarities in African-American crack cocaine abusers. J Nerv Ment Dis 183: 260-266.

Lynch WJ, Roth ME, Mickelberg JL, Carroll ME (2001). Role of estrogen in the acquisition of intravenously self-administered cocaine in female rats. Pharmacol Biochem Behav 68: 641-646.

Lynch WJ, Roth ME, Carroll ME (2002). Biological basis of sex differences in drug abuse: preclinical and clinical studies. Psychopharmacology 164: 121-137.

McCance-Katz EF, Carroll KM, Rounsaville BJ (1999). Gender differences in treatment-seeking cocaine abusers-implications for treatment and prognosis. Am J Addict 8: 300-311.
McCarthy MM, Schlenker EH, Pfaff DW (1993). Enduring consequences of neonatal treatment with antisense oligodeoxynucleotides to estrogen receptor messenger ribonucleic acid on sexual differentiation of rat brain. Endocrinology 133: 433-439.

McCarthy MM, Masters DB, Rimvall K, Schwartz-Giblin S, Pfaff DW (1994). Intracerebral administration of antisense oligodeoxynucleotides to GAD65 and GAD67 mRNAs modulate reproductive behavior in the female rat. Brain Res 636: 209-220.

McCarthy MM, Auger AP, Mong JA, Sickel MJ, Davis AM (2000). Antisense oligodeoxynucleotides as a tool in developmental neuroendocrinology. Methods 22: 239-248.

Mermelstein PG, Becker JB (1995). Increased extracellular dopamine in the nucleus accumbens and striatum of the female rat during paced copulatory behavior. Behav Neurosci 109: 354-365.

Morgan MA, Pfaff DW (2001). Effects of estrogen on activity and fear-related behaviors in mice. Horm Behav 40: 472-482.

Morgan MA, Pfaff DW (2002). Estrogen's effects on activity, anxiety, and fear in two mouse strains. Behav Brain Res 132: 85-93.

Moss RL, Gu Q (1999). Estrogen: mechanisms for a rapid action in CA1 hippocampal neurons. Steroids 64: 14-21.

Nilsen J, Chen S, Brinton RD (2002). Dual action of estrogen on glutamate-induced calcium signaling: mechanisms requiring interaction between estrogen receptors and src/mitogen activated protein kinase pathway. Brain Res 930: 216-234.

Niyomchai T, Russo SJ, Festa ED, Akhavan A, Jenab S, QuinonesJenab V (2005). Progesterone inhibits behavioral responses and estrogen increases corticosterone levels after acute cocaine administration. Pharmacol Biochem Behav 80: 603-610.

Nomikos GC, Spyraki C (1988). Influence of oestrogen on spontaneous and diazepam-induced exploration of rats in an elevated plus maze. Neuropharmacology 27: 691-696.

Ogawa S, Olazabal UE, Parhar IS, Pfaff DW (1994). Effects of intrahypothalamic administration of antisense DNA for progesterone receptor mRNA on reproductive behavior and progesterone receptor immunoreactivity in female rat. J Neurosci 14: $1766-1774$

Ogawa S, Chan J, Gustafsson JA, Korach KS, Pfaff DW (2003). Estrogen increases locomotor activity in mice through estrogen receptor $\alpha$ : specificity for the type of activity. Endocrinology 144: 230-239.

Paxinos G, Watson C (1986). The Rat Brain in Stereotaxic Coordinates. Academic Press: New York, NY.

Peris J, Decambre N, Coleman-Hardee ML, Simpkins JW (1991). Estradiol enhances behavioral sensitization to cocaine and amphetamine-stimulated striatal $\left[{ }^{3} \mathrm{H}\right]$ dopamine release. Brain Res 566: 255-264.

Pfaff D, Frohlich J, Morgan M (2002). Hormonal and genetic influences on arousal-sexual and otherwise. Trends Neurosci 25: $45-50$.

Pfaff DW, McEwen BS (1983). Action of estrogens and progestins on nerve cells. Science 219: 808-814.

Pfaus JG, Damsma G, Wenkstern D, Fibiger HC (1995). Sexual activity increases dopamine transmission in the nucleus accumbens and striatum of female rats. Brain Res 693: 21-30.

Rachman IM, Unnerstall JR, Pfaff DW, Cohen RS (1998). Estrogen alters behavior and forebrain c-fos expression in ovariectomized rats subjected to the forced swim test. Proc Natl Acad Sci USA 95: 13941-13946.

Rhodes ME, Frye CA (2006). ER $\beta$-selective SERMs produce mnemonic effects in the inhibitory avoidance and water maze tasks. Neurobiol Learn Mem 85: 183-191.

Rocha BA, Fleischer R, Schaeffer JM, Rohrer SP, Hickey GJ (2005). $17 \beta$-Estradiol-induced antidepressant-like effect in the Forced Swim Test is absent in estrogen receptor- $\beta$ knockout (BERKO) mice. Psychopharmacology 179: 637-643. 
Roth ME, Carroll ME (2004). Sex differences in the escalation of intravenous cocaine intake following long- or short-access to cocaine self-administration. Pharmacol Biochem Behav 78: 199-207.

Saletu B, Brandstatter N, Metka M, Stamenkovic M, Anderer P, Semlitsch HV et al (1995). Double-blind, placebo-controlled, hormonal, syndromal and EEG mapping studies with transdermal oestradiol therapy in menopausal depression. Psychopharmacology 122: 321-329.

Schleifer LA, Justice AJ, de Wit H (2002). Lack of effects of acute estradiol on mood in postmenopausal women. Pharmacol Biochem Behav 71: 71-77.

Schreihofer DA, Rowe DF, Rissman EF, Scordalakes EM, Gustafsson JA, Shupnik MA (2002). Estrogen receptor- $\alpha$ (ER $\alpha)$, but not $\mathrm{ER} \beta$, modulates estrogen stimulation of the $\mathrm{ER} \alpha$ truncated variant, TERP-1. Endocrinology 143: 4196-4202.

Sell SL, Thomas ML, Cunningham KA (2002). Influence of estrous cycle and estradiol on behavioral sensitization to cocaine in female rats. Drug Alcohol Depend 67: 281-290.

Shughrue PJ, Merchenthaler I (2001). Distribution of estrogen receptor beta immunoreactivity in the rat central nervous system. J Comp Neurol 436: 64-81.

Shughrue PJ, Lane MV, Merchenthaler I (1997). Comparative distribution of estrogen receptor- $\alpha$ and $-\beta$ mRNA in the rat central nervous system. J Comp Neurol 388: 507-525.

Shughrue PJ, Scrimo PJ, Merchenthaler I (1998). Evidence for the colocalization of estrogen receptor- $\beta$ mRNA and estrogen receptor- $\alpha$ immunoreactivity in neurons of the rat forebrain. Endocrinology 139: 5267-5270.

Slater J, Blizard DA (1976). A reevaluation of the relation between estrogen and emotionality in female rats. J Comp Physiol Psychol 90: 755-764.

Smith RN, Studd JW, Zamblera D, Holland EF (1995). A randomised comparison over 8 months of 100 micrograms and 200 micrograms twice weekly doses of transdermal oestradiol in the treatment of severe premenstrual syndrome. $\mathrm{Br} J$ Obstet Gynaecol 102: 475-484.

Snow D, Anderson C (2000). Exploring the factors influencing relapse and recovery among drug and alcohol addicted women. J Psychosoc Nurs Ment Health Serv 38: 8-19.

Steiner M, Katz RJ, Carroll BJ (1982). Detailed analysis of estrousrelated changes in wheel running and self-stimulation. Physiol Behav 28: 201-204.

Substance Abuse and Mental Health Services Administration, SAMHSA (2004). Summary of Findings from the 2004 National Household Survey on Drug Abuse. Office of Applied Studies, NHSDA: Rockville, MD.

Swan GE, Denk CE, Parker SD, Carmelli D, Furze CT, Rosenman RH (1988). Risk factors for late relapse in male and female exsmokers. Addict Behav 13: 253-266.

Tanabe F, Miyasaka N, Kubota T, Aso T (2004). Estrogen and progesterone improve scopolamine-induced impair spatial memory. J Med Dent Sci 51: 89-98.

Tanaka M, Ohtani-Kaneko R, Yokosuka M, Watanabe C (2004). Low-dose perinatal diethylstilbestrol exposure affected behaviors and hypothalamic estrogen receptor- $\alpha$-positive cells in the mouse. Neurotoxicol Teratol 26: 261-269.
Toran-Allerand CD (2004). Minireview: a plethora of estrogen receptors in the brain: where will it end? Endocrinology 145: 1069-1074.

Toran-Allerand CD, Guan X, MacLusky NJ, Horvath TL, Diano S, Singh $M$ et al (2002). ER-X: a novel, plasma membraneassociated, putative estrogen receptor that is regulated during development and after ischemic brain injury. J Neurosci 22: 8391-8401.

Vasudevan N, Kow LM, Pfaff DW (2001). Early membrane estrogenic effects required for full expression of slower genomic actions in a nerve cell line. Proc Natl Acad Sci USA 98: $12267-12271$.

Wade CB, Robinson S, Shapiro RA, Dorsa DM (2001). Estrogen receptor (ER) $\alpha$ and ER $\beta$ exhibit unique pharmacologic properties when coupled to activation of the mitogen-activated protein kinase pathway. Endocrinology 142: 2336-2342.

Walf AA, Frye CA (2005a). Estradiol's effects to reduce anxiety and depressive behavior may be mediated by estradiol dose and restraint stress. Neuropsychopharmacology 30: 1288-1301.

Walf AA, Frye CA (2005b). ER $\beta$-selective estrogen receptor modulators produce antianxiety behavior when administered systemically to ovariectomized rats. Neuropsychopharmacology 30: 1598-1609.

Walf AA, Frye CA (2006). A review and update of: mechanisms of estrogen in the hippocampus and amygdala for anxiety and depression behavior. Neuropsychopharmacology 31: 1097-1111.

Walf AA, Rhodes ME, Frye CA (2004). Anti-depressant effects of $\mathrm{ER} \beta$ selective estrogen receptor modulators in the forced swim test. Pharm Biochem Behav 78: 523-529.

Walf AA, Rhodes ME, Frye CA (2006). Ovarian steroids enhance object recognition in naturally cycling and ovariectomized, hormone-primed rats. Neurobiol Learn Mem, 8 March [Epub ahed of print].

Watanabe T, Inoue S, Ogawa S, Ishii Y, Hiroi H, Ikeda $\mathrm{K}$ et al (1997). Agonistic effect of tamoxifen is dependent on cell type, ERE-promoter context, and estrogen receptor subtype: functional difference between estrogen receptors $\alpha$ and $\beta$. Biochem Biophys Res Commun 236: 140-145.

Watters JJ, Campbell JS, Cunningham MJ, Krebs EG, Dorsa DM (1997). Rapid membrane effects of steroids in neuroblastoma cells: effects of estrogen on mitogen activated protein kinase signalling cascade and c-fos immediate early gene transcription. Endocrinology 138: 4030-4033.

White NM, Carr GD (1985). The conditioned place preference is affected by two independent reinforcement processes. Pharmacol Biochem Behav 23: 37-42.

Xiao L, Becker JB (1997). Hormonal activation of the striatum and the nucleus accumbens modulates paced mating behavior in the female rat. Horm Behav 32: 114-124.

Xiao L, Jackson LR, Becker JB (2003). The effect of estradiol in the striatum is blocked by ICI 182780 but not tamoxifen: pharmacological and behavioral evidence. Neuroendocrinology 77: 239-245.

Zhou Y, Dorsa DM (1994). Estrogen rapidly induces c-jun immunoreactivity in rat striatum. Horm Behav 28: 376-382. 